Journal of Economic Theory 12 (2-6): 28-33, 2018

ISSN: 1994-8212

(C) Medwell Journals, 2018

\title{
The Relationship Between Macroeconomic Factor and Condominium Business Growth in Thailand
}

\author{
Ditthawat Sopitarpapong and Vichayanan Rattanawiboonsom \\ Faculty of Business, Economics and Communication, Naresuan University, Phitsanulok, Thailand
}

\begin{abstract}
The purpose of this research is to study the relationship between macroeconomic factor and condominium business growth in Thailand. This study used 70-quarter secondary data from the first quarter of 2000 to the second quarter of 2017. The data were then analyzed using linear regression (multiple regressions) and a software program to test the hypothesis and to test the relationship between independent variables and dependent variables. The factors that have been studied among 3 sectors: the gross domestic product, business sentiment index and real estate promotion policy in Thailand with the number of condominium registered by consumers from 2000 until second quarter of 2017 are related and different. Which factor measures have significant implications for the growth of the condominium business? The results show that only the gross domestic product to significantly and affect condominium growth at the statistical significance level of 0.01 and unaffected for business sentiment index because It may be just a point view of an entrepreneur to perception and belief. The last factor real estate promotion policy in Thailand unaffected too because promotion not align with economic cycle. This may not have the effect increasing condominium business in Thailand.
\end{abstract}

Key words: Thailand real estate promotion, growth of Thailand condominium, condominium registration, promotion policy, economic cycle, business in Thailand

\section{INTRODUCTION}

Thailand located in center of Southeast Asia, occupying $513,120 \mathrm{~km}^{2}$, the world's 50 th in terms of space. Thailand is the 20th largest population in the world, accounting for 68 million people and GDP 2016 growth $14,366,557$ million baht. The economy ranking 26 th largest number in the world (Chuenchoksan, 2014). There are many factors in the growth of Thailand and the real estate sector is considered as a real business sector supporting the country's economic growth (NAHB., 2017) related on raw material, production and service to employment for 2.9 million people. For financial sector related or money sector will be impact to funds, savings and loans. At the micro level, housing is one of the four essential factors of living. It is also a source of wealth and can be used as collateral for loans from financial institutions. And household debt is the greatest proportion in household debt $(36 \%)$. The real estate sector is very important to the growth of Thailand. When analyzing the growth, since, 2009 it has changed dramatically the ratio of registered condominiums has reached $57 \%$ total number of registered property and increasing up to $63 \%$ in 2012 (BT., 2014). It is an interesting question as to which factors affect the growth of the condominium sector.

Real Estate Association of Thailand to study and analysis to real estate sector with economic factor from 1968 until 2006 there are study factors gross domestic product, volume of housing transfer, government policy and relatives as shown in Fig. 1.

\section{Research objective:}

- To study macroeconomic factor related to condominium business

- To study relationship between the gross domestic product, business sentiment index and real estate promotion policy with the number of condominium registered in Thailand

- To test hypothesis the gross domestic product, business sentiment index and real estate promotion policy with the number of condominium registered in Thailand (Fig. 2)

\section{Expected benefits:}

- To describe the influence relationships between macroeconomic factor and the growth of condominium business

- To use research results can be used as data for business analysis and decision making of property development companies

- To establish academic knowledge related to real estate management as information and decision-making for the public and private sectors in developing Thailand countries

Corresponding Author: Ditthawat Sopitarpapong, Faculty of Business, Economics and Communication, Naresuan University, Phitsanulok, Thailand 


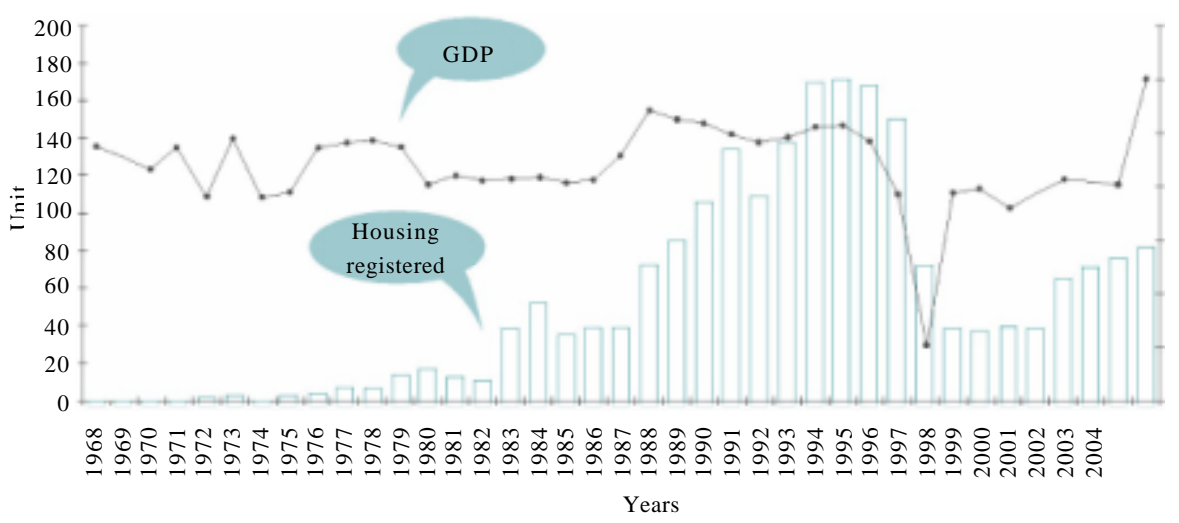

Fig. 1: The gross domestic product in comparison with the volume of residence registered between 1968 until 2006. Government Housing Bank

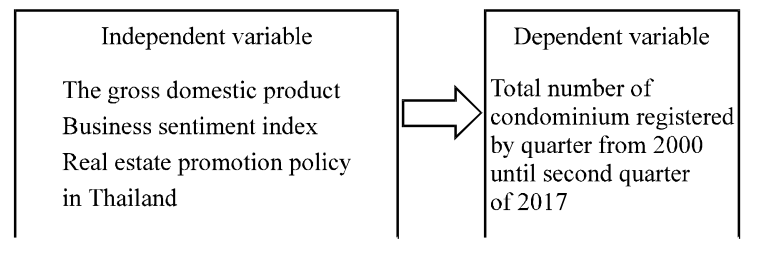

Fig. 2: Conceptual framework

Literature review: Based on the theory of macroeconomics to focuses on the overall economic in each country, so that, the economy mission can operate efficiently, fairness, freedom and stably (Anonymous, 2015). The analysis and study of the overall economic activity consists is Gross Domestic Product (GDP) in the market value of the final goods and services produced in the country at frequency time (Chantapong and Tunsri, 2013). This has directly affected the growth of the condominium business. This is consistent with the data analysis of the real estate data center showing the relationship between gross domestic product and the number of residential units completed in Bangkok in 1991-2012 significantly above illustrates the fact that support for assumption hypothesis 1 that gross domestic product is positively correlated with the growth of condominium business.

For the study, research and development of the concept (Kirdpibul and Kirdpibul, 1989). The index of business confidence is used as a guide for planning and conducting economic activities in the private and public sectors in Thailand. The survey data will focus only on 6 branches. The ISIC system is used: International Standard Industrial Classification of All Economic Activities from The United Nations determines the activities of businesses surveyed. For construction, the main activity is the construction of houses. It is a database to index. At the same time, the Business Sentiment Index of Q3 2012 (Thongsom, 2013), the business sector has a current confidence index of 51.3 which is higher than the average. 50.0 Business executives have a positive sentiment toward condominium business growth and are consistent with the economic factors affecting the set index (Hiratsuka, 1991). Concluded that the BSI correlation coefficient was found to be significantly correlated with the real estate market index at 0.05 . Is very high this shows the reason for supporting the hypothesis 2 Business Sentiment Index is positively correlated with the growth of condominium business.

For the government's policy of taking special measures in real estate to effect business expansion, first launched in 1997 Office of the National Economic and Social Development Board. Construction branch Grew by $6.8 \%$ support by; the real estate promotion from government to expired in June 2010, enabling customers and operators to accelerate their transfer to take advantage of promotion. The interest rate is low and the real interest rate is negative. The development of public sector infrastructure which has led to a proliferation of demand for property in nearby areas. Economic recovery and consumer confidence. In addition, the economic and financial summary 2009 (BT., 2012), the real estate sector expanded from the demand, reflecting the $9.6 \%$ growth in the registration of housing ownership in Bangkok and its vicinities. Housing due to the uncertainty of renewed stimulus measures, the government's property sector will end in March 2009. Based on the review of relevant data and articles. This shows the reason for supporting the hypothesis 3 real estate promotion policy is positively correlated with the growth of condominium business. Researchers have reviewed literature related to the conclusion of the real estate promotion as Table 1. 
Table 1: omparison real estate promotion policy between 2008,2011 and 2015

\begin{tabular}{|c|c|c|c|}
\hline Promotion & 2008 & 2011 & 2015 \\
\hline Value tax & $\begin{array}{l}\text { Reduce } 3.3-0.11 \% \text { for residential sellers } \\
\text { from March } 29,2008-28,2010\end{array}$ & & \\
\hline Transfer fees & $\begin{array}{l}\text { Reduce } 2-0.01 \% \text { for both buy ers and sellers } \\
\text { from March } 29,2008-28,2010\end{array}$ & & $\begin{array}{l}\text { Reduced from } 2-0.01 \% \text { for both } \\
\text { buyers and sellers from October } 19 \text {, } \\
2015 \text {-April } 19,2016\end{array}$ \\
\hline Mortgage fee & $\begin{array}{l}\text { Reduce } 1-0.01 \% \text { for residential buyers } \\
\text { from March } 29,2008-28,2010\end{array}$ & & $\begin{array}{l}\text { Reduce } 1-0.01 \% \text { for residential buyers } \\
\text { from } 19 \text { Oct. } 2015-19 \text { Apr } 2016\end{array}$ \\
\hline $\begin{array}{l}\text { Personal } \\
\text { income tax }\end{array}$ & $\begin{array}{l}\text { Expansion of the personal income tax deduction } \\
\text { for the purchase of housing from } 50,000 \text { baht to } \\
100,000 \text { baht. The deduction of living expenses } \\
\text { transferred from } 2009 \text { will not be deducted from } \\
\text { personal income tax. } 3 \text { hundred thousand } \\
\text { per person }\end{array}$ & $\begin{array}{l}\text { Deductible from personal income tax, } \\
\text { the cost to buy a first-class residential } \\
\text { property that is not more than } 5 \text { million } \\
\text { baht with a } 10 \% \text { discount on property } \\
\text { value for a period of } 5 \text { years. Equally, } \\
\text { it must be a property purchase. And } \\
\text { registration transfer between September } \\
21,2011 \text {-December } 31,2012\end{array}$ & $\begin{array}{l}\text { Deduction from personal income tax. } \\
\text { The cost to purchase a first-class } \\
\text { residential property worth no more } \\
\text { than } 3 \text { million baht, } 20 \% \text { of the value } \\
\text { of the property for a period of } 5 \text { years, } \\
\text { will be deducted. It is buying property. } \\
\text { And registered transfer of ownership } \\
\text { between } 19 \text { October } 2556-31 \\
\text { December } 2016\end{array}$ \\
\hline H. debt/GDP (\%) & 52.4 & 66.2 & 80.6 \\
\hline NPL (\%) & 7.9 & 4.9 & 3.3 \\
\hline
\end{tabular}

TRIS rating Co., Ltd

\section{MATERIALS AND METHODS}

Secondary data of three independence factors from the gross domestic product, business sentiment index, real estate promotion policy in Thailand with one dependence the number of condominium registered by consumers from 2000 until second quarter of 2017 , totaling 70 data sets.

Multiple regressions were used to calculate the statistics using SPSS to test hypothesis and to test the relationship between independent variables and dependence variables. The Pearson correlation coefficient used to determine the degree and direction of relatedness between two variables. The possible values of the correlation coefficient range from -1.00 to +1.00 and the closer the number is to an absolute value of 1.00 , the greater the degree of relatedness. As with Chi square, the Pearson correlation coefficient can be tested for statistical significance level at 0.05 (Chamornsawat and Khongsawatkiat, 2013).

\section{RESULTS AND DISCUSSION}

The relationship assumptions between Macroeconomic Factor and Condominium Business Growth in Thailand. Can be written as a statistical hypothesis:

Hypothesis 1: The gross domestic product impact growth of condominium in Thailand

- $\mathrm{H}_{0}$ : the gross domestic product not impact growth of condominium in Thailand

- $\mathrm{H}_{1}$ : the gross domestic product impact growth of condominium in Thailand
Table 2: Pearson correlation coefficient

\begin{tabular}{ll}
\hline Coefficient value & Strength of association \\
\hline $0.1<|\mathrm{r}|<.3$ & Small correlation \\
$0.3<|\mathrm{r}|<.5$ & Medium correlation \\
$|\mathrm{r}|>.5$ & Strong correlation
\end{tabular}

Table 3: Variance tests hypothesis 1

Correlation between $\quad$ Pearson (r) Sig. Correlation level \begin{tabular}{llll}
\hline GDP and growth of condominium & $0.841^{* *}$ & 0.000 & Strong
\end{tabular}

** Significant at 0.01 level

For the statistics used pearson correlation coefficient (r) or bivariate correlation to analys is the linear correlation between variables. It has a value between +1 and -1 where 1 is total positive linear correlation, 0 is no linear correlation and -1 is total negative linear correlation to breakdown on Table 2 (Chamornsawat and Khongsawatkiat, 2013). The results of the pearson correlation between variance in hypothesis 1 were shown in Table 3.

The pearson correlation test showed that Sig. value (2-tailed) $=0.000$ more than 0.01 which mean that to reject the null hypothesis $\left(\mathrm{H}_{0}\right)$ and accept $\left(\mathrm{H}_{1}\right)$ The gross domestic product impact growth of condominium in Thailand and person correlation value $=0.841$ which mean that positive linear correlation in strong correlation level.

Hypothesis 2: business sentiment index impact growth of condominium in Thailand:

- $\mathrm{H}_{0}$ : business sentiment index not impact growth of condominium in Thailand

- $\mathrm{H}_{1}$ : business sentiment index impact growth of condominium in Thailand

The results of the pearson correlation between variance in hypothesis 2 were shown in Table 4. 
Table 4: Variance tests hypothesis 2

\begin{tabular}{llll}
\hline Correlation between & Pearson ( $r$ ) & Sig. & Correlation level \\
\hline
\end{tabular}
\begin{tabular}{llll}
\hline BSI and growth of condominium & 0.205 & 0.088 & small
\end{tabular}

Table 5: Variance tests hypothesis 3

\begin{tabular}{llll}
\hline Correlation between & Pearson $(\mathrm{r})$ & Sig. & Level \\
\hline $\begin{array}{l}\text { Promotion policy and growth of } \\
\text { condominium }\end{array}$ & $-0.306^{* * *}$ & 0.010 & Medium \\
**Significant at 0.01 level & & & \\
\hline Sing & & &
\end{tabular}

The Pearson correlation test showed that Sig. value $=0.088<0.05$ which mean that to reject the null hypothesis $\left(\mathrm{H}_{1}\right)$ and accept $\left(\mathrm{H}_{0}\right)$ business sentiment index not impact growth of condominium in thailand and person correlation value $=0.205$ which mean that small correlation level.

Hypothesis 3: Real estate promotion policy in Thailand impact growth of condominium in Thailand:

- $\mathrm{H}_{0}$ : real estate promotion policy in Thailand not impact growth of condominium in Thailand

- $\mathrm{H}_{1}$ : real estate promotion policy in Thailand impact growth of condominium in Thailand

The results of the pearson correlation between variance in hypothesis 3 were shown in Table 5 .

The pearson correlation test showed that Sig. value (2-tailed) $=0.010$ more than 0.01 which mean that to reject the null hypothesis $\left(\mathrm{H}_{0}\right)$ and accept $\left(\mathrm{H}_{1}\right)$ real estate promotion policy in Thailand impact growth of condominium in Thailand but person correlation value $=-0.306$ which mean that negative linear correlation can be to summarize real estate promotion policy in Thailand impact decreasing growth of condominium in Thailand in medium correlation level (Table 4 and 5).

For this research, it was found that the GDP impact with growth of condominium. Gross domestic product is the best way to measure a country's economy. GDP is the total value of everything produced by all the people and companies in the country. It doesn't matter if they are citizens or Foreign-owned companies. If they are located within the country's boundaries, the government counts their production. This is consistent with the results of the analysis by (Anonymous, 2017) housing's combined contribution to GDP, generally, averages $15-18 \%$ and occurs in two basic ways:

Residential investment (averaging roughly 3-5\% of (GDP) which includes construction of new single-family and multifamily structures, residential remodeling, production of manufactured homes and broker's fees.
Consumption spending on housing services (averaging roughly $12-13 \%$ of GDP) which includes gross rents and utilities paid by renters as well as owner's imputed rents and utility payments (Table 6).

This is consistent with the data analysis Real Estate Association of Thailand to study and analysis to real estate sector with economic factor from 1968 until 2006 there are study factors gross domestic product and volume of housing transfer in Thailand as shown in Fig. 1 that's why the resulted to show strong correlation level.

For business sentiment index not impact growth of condominium because BSI is based on enterprise's assessment of production, orders and stocks as well as its current position and expectations for the immediate future. Opinions compared to a "normal" state are collected and the difference between positive and negative answers provides a qualitative index on economic conditions (Anonymous, 2017).

And found to be consistent with analysis report from (BT., 2012) found that the problems encountered by indexing from response rate is lower about $60 \%$ and the distribution of the sample is different from the proportion of activity in the economy. The number of samples in some sectors is too small to reflect the real economy. As a result, the proportion of sample size distribution is high (Error ratio).

For Real Estate Promotion Policy did not affect the growth of condominium registration volume. Therefore, for the volume of condominium registration is a real supply there may be other factors involved that will affect example bank loan policy, Interest rate and promotions of real estate development companies and alignment study economic cycle in UK. from 1921-1997 economic cycles in each period take 4-12 years with an average of 8 years. The "growth" will be in the 2-7 years and the regression will be in 2-9 years which concludes that the real estate cycle and economic cycle is interrelated. The real estate cycle follows the economic cycle because real estate is a variable while the economy is an independent variable.

Another factor reduced the proportion of registered housing that the higher household debt burden since 2008 has resulted affecting the volume of condominium registration from ownership transfer.

For what was discovered in this study between 2008 and 2015 it was found that promotion in 2015 more affected the condominium registered property in significantly. The promotion is being implemented from October 2015-April 2016. The focus of the difference: 


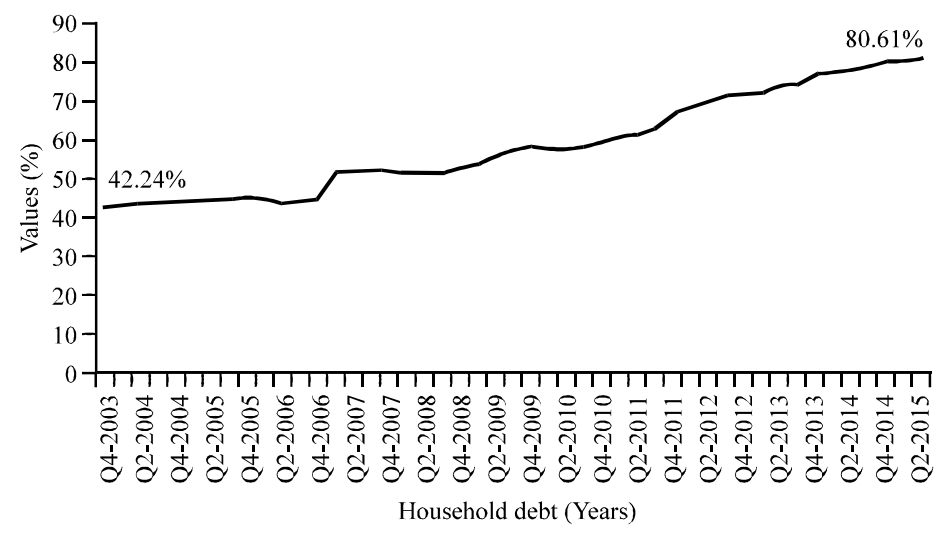

Fig. 3: Household debt from 2003-2015 (BT., 2015)

\begin{tabular}{|c|c|c|c|c|c|c|c|c|c|c|c|c|c|c|c|}
\hline \multirow[b]{2}{*}{ Veriables } & \multicolumn{15}{|c|}{ Housing's contribution to GDP } \\
\hline & 1980 & 1985 & 1990 & 1995 & 2000 & 2005 & 2010 & 2015 & 2016 & $2016(02)$ & $2016(03)$ & $2016(03)$ & $2017(01)$ & $2017(02)$ & $2017(03)$ \\
\hline \multicolumn{16}{|l|}{$\begin{array}{l}\text { Constant doll ars } \\
\text { (Billions, 2009) }\end{array}$} \\
\hline Gross domestic product & 6.450 & 7.594 & 8.955 & 10.175 & 12.560 & 14.234 & 14.784 & 16.472 & 16.716 & 16.664 & 16.778 & 16.851 & 16.903 & 17.031 & 17.157 \\
\hline $\begin{array}{l}\text { Gross private domestic } \\
\text { investment }\end{array}$ & 881 & 1.160 & 1.241 & 1.551 & 2.376 & 2.673 & 2.120 & 2.905 & 2.858 & 2.830 & 2.847 & 2.906 & 2.897 & 2.925 & 2.968 \\
\hline Residential fixed investment & 333 & 417 & 420 & 495 & 638 & 873 & 382 & 557 & 587 & 587 & 580 & 590 & 606 & 594 & 585 \\
\hline $\begin{array}{l}\text { Personal consumption } \\
\text { expenditures }\end{array}$ & 3.991 & 4.812 & 5.673 & 6.528 & 8.171 & 9.532 & 10.036 & 11.264 & 11.572 & 11.538 & 11.618 & 11.702 & 11.758 & 11.853 & 11.922 \\
\hline Housing services & 821 & 966 & 1.138 & 1.300 & 1.574 & 1.777 & 1.904 & 1.999 & 2.025 & 2.025 & 2.035 & 2.031 & 2.029 & 2.046 & 2.047 \\
\hline $\begin{array}{l}\text { Residential fixed investment+ } \\
\text { Housing services } \\
\text { Percentage of GDP }\end{array}$ & 1.154 & 1.383 & 1.558 & 1.796 & 2.212 & 2.650 & 2.287 & 2.556 & 2.613 & 2.611 & 2.615 & 2.620 & 2.634 & 2.640 & 2.632 \\
\hline Residential Fixedinvestment & 5.2 & 5.5 & 4.7 & 4.9 & 5.1 & 6.1 & 2.6 & 3.4 & 3.5 & 3.5 & 3.5 & 3.5 & 3.6 & 3.5 & 3.4 \\
\hline Housing services & 12.7 & 12.7 & 12.7 & 12.8 & 12.5 & 12.5 & 12.9 & 12.1 & 12.1 & 12.1 & 12.1 & 12.1 & 12.0 & 12.0 & 11.9 \\
\hline $\begin{array}{l}\text { Residential fixed investment }+ \\
\text { Housing services } \\
\text { Contribution to real } \\
\text { GDP growth }\end{array}$ & 17.9 & 18.2 & 17.4 & 17.7 & 17.6 & 18.6 & 15.5 & 15.5 & 15.6 & 15.7 & 15.6 & 15.6 & 15.6 & 15.5 & 15.3 \\
\hline $\begin{array}{l}\text { Gross domestic product } \\
\text { growth (\%) }\end{array}$ & -0.2 & 4.2 & 1.9 & 2.7 & 4.1 & 3.3 & 2.5 & 2.6 & 1.6 & 2.2 & 2.8 & 1.8 & 1.2 & 3.1 & 3.0 \\
\hline $\begin{array}{l}\text { Personal consumption } \\
\text { expenditures }(\%)\end{array}$ & -0.2 & 3.3 & 1.3 & 1.9 & 3.3 & 2.4 & 1.3 & 2.5 & 1.9 & 2.6 & 1.9 & 2.0 & 1.3 & 2.2 & 1.6 \\
\hline Housing services (\%) & 0.4 & 0.5 & 0.2 & 0.4 & 0.4 & 0.5 & 0.2 & 0.2 & 0.2 & 0.4 & 0.3 & -0.1 & 0.0 & 0.4 & 0.0 \\
\hline $\begin{array}{l}\text { Gross private domestic } \\
\text { investment (\%) }\end{array}$ & -2.1 & 0.0 & -0.5 & 0.6 & 1.3 & 1.2 & 1.7 & 0.9 & -0.3 & -0.5 & 0.4 & 1.3 & -0.2 & 0.6 & 1.0 \\
\hline $\begin{array}{l}\text { Residential fixed } \\
\text { investment (\%) }\end{array}$ & -1.2 & 0.1 & -0.4 & -0.2 & 0.0 & 0.4 & -0.1 & 0.3 & 0.2 & -0.2 & -0.2 & 0.3 & 0.4 & -0.3 & -0.2 \\
\hline $\begin{array}{l}\text { Government expenditures } \\
\text { and investment (\%) }\end{array}$ & 0.0 & -0.1 & -0.1 & -0.1 & -0.3 & -0.1 & -0.1 & -0.1 & -0.1 & -0.2 & 0.1 & 0.0 & -0.1 & 0.0 & 0.0 \\
\hline $\begin{array}{l}\text { Net exports of goods and } \\
\text { services (\%) }\end{array}$ & -0.9 & -1.0 & -0.2 & -0.4 & -0.1 & 0.0 & 1.5 & 0.2 & -0.4 & 0.3 & 0.4 & -1.6 & 0.2 & 0.2 & 0.4 \\
\hline
\end{tabular}

- Low-income purchasing people

- $\mathrm{GHB}$ special loan for home not exceeding $3 \mathrm{MB}$

- Raising the personal income tax deductible

- Tax reduction of up to $20 \%$ is 5 year's tax breaks

The cut-off is that there is no specific business tax deduction on real estate sales like in 2008 because the benefits of a specific business tax reduction will only benefit real estate developers that's why resulted to show decreasing condominium growth (Fig. 3 and Table 7).

\begin{tabular}{lll}
\multicolumn{3}{l}{ Table 7: Compare promotion between 2008 and 2015 } \\
\hline Promotion & 2008 & 2015 \\
\hline Value tax & $\begin{array}{l}\text { Reduce 3.3-0.11\% for } \\
\text { residential sell ers from }\end{array}$ & \\
& March 29,2008-28, 2010 & \\
Transfer & Reduce 2-0.01\% for both & Reduced from 2-0.01\% for \\
fees & buyers and sellers from & both buyers and sellers \\
& March 29, 2008-28, 2010 & from October 19, 2015-Apri1 \\
& & 19,2016 \\
Mortgage & Reduce 1\% to 0.01\% for & Reduce 1-0.01\% for \\
fee & residential buyers from & residential buyers from 19 \\
& March 29,2008-28, & October 2015-19 \\
& 2010 & Apr 2016 \\
\hline
\end{tabular}




\section{CONCLUSION}

It is interesting to study that the growth of the condominium business is related to the economic factors that can be planned and developed economic of Thailand.

\section{REFERENCES}

Anonymous, 2015. Real estate promotion policy. TRIS Rating Co., Ltd, Bangkok, Thailand.

Anonymous, 2017. Business tendency and consumer opinion surveys. The Organisation for Economic Co-operation and Development, Paris, France.

BT., 2012. Thailand economic outlook 2012. Bank of Thailand, Fiscal Policy Office, Ministry of Finance, Bangkok, Thailand.

BT., 2014. Thailand economic outlook 2014. Financial Stability Report for Thailand 2013. Bank of Thailand, Bangkok, Thailand.

Chamornsawat, J. and K. Khongsawatkiat, 2013. Economic factors that affecting the stock index of property development groups in Stock Exchange of Thailand. J. Finance Investment Marketing Bus. Manage., 2: 303-319.
Chuenchoksan, S., 2014. Thai household debt on economic implications. Bank of Thailand, Bangkok, Thailand.

Hiratsuka, D., 1991. The Causes of Business Cycles in Thailand. In: Business Cycles in Asia, Osada, H. and D. Hiratsuka (Eds.). Institute of Developing Economies, Tokyo, Japan, pp: 104-112.

Kirdpibul, J. and U. Kirdpibul, 1989. Study on the pattern of continuous cycle between production and marketing of fruits and vegetables exported in the North National Research Council of Thailand. Bangkok, Thailand.

NAHB., 2017. Housing's contribution to gross domestic product. National Housing Center, Washington, USA. https://www.nahb.org/en/research/ housing-economics/housings-economic-impact/ho usings-contribution-to-gross-domestic-product-gd p.aspx

Thongsom, P., 2013. Leading economic index: LEI. Office of Small and Medium Enterprises Promotion, Bangkok, Thailand. 